\title{
Gaseous Decomposition Products from Wood Degradation via Thermogravimetric and Fourier Transform Infrared Analysis during Thermal Modification of Beech and Pine Woods
}

\author{
Zhengbin He, Zhengyu Wang, Lijie Qu, Jing Qian, and Songlin Yi *
}

\begin{abstract}
Wood thermal modification is an environmentally friendly method used to improve wood characteristics, and its degradation mechanism directly influences its application in construction, building, and home decoration. Combined thermogravimetry and Fourier transform infrared (TG-FTIR) studies were conducted to evaluate the hardwood and softwood on-site at $160{ }^{\circ} \mathrm{C}$ and $220^{\circ} \mathrm{C}$. The results indicated that the mass loss rates (MLRs) for both hardwood and softwood samples decreased over time and ultimately became constant. The total mass loss increased with an increase in temperature. The total mass loss was about $3 \%$ at $160{ }^{\circ} \mathrm{C}$, and about $4.7 \%$ to $6.5 \%$ at $220{ }^{\circ} \mathrm{C}$. Decomposition also occurred much more easily in the hardwood than in the softwood. More species of gas products were emitted from hardwood than softwood, and the number of species of gas products increased with an increase in temperature and processing time. The FTIR spectra of softwood were similar, whereas those of hardwood were remarkably different at different temperatures. Water and alcohol were generated from both the hardwood and softwood, whereas contents of these gaseous products were visible in hardwood decomposed at $220{ }^{\circ} \mathrm{C}$ during the thermal treatment. Ketones, ethers, acids, and aromatics were found in both hardwood and softwood, whereas $\mathrm{CO}_{2}$ was only found in the hardwood that underwent thermal treatment.
\end{abstract}

Keywords: FTIR; Thermostability; Decomposition; Mass loss; Gas product; Generation mechanism

Contact information: Beijing Key Laboratory of Wood Science and Engineering, College of Material Science and Technology, Beijing Forestry University, No. 35, Qinghua East Road, Haidian District, Beijing, 100083, P.R. China; Corresponding authors: hzbcailiao@bjfu.edu.cn; ysonglin@bjfu.edu.cn

\section{INTRODUCTION}

Wood, a renewable and natural material, has been widely used in construction, building, and wood processing (Wang et al. 2018) because of its high strength-to-weight ratio, high processability, environmental friendliness, and degradation (Popescu and Popescu 2013; Li et al. 2017). However, as a type of porous medium (Keey et al. 2012), wood can shrink and swell when it desorbs and absorbs moisture because of hygroexpansion and anisotropy (Skaar 1988; He and Yi 2016). Thus, these characteristics markedly shorten the service life and value of wood products and limit its broad application.

Wood thermal modification is an environmentally friendly method and has been widely used to improve dimensional stability (Rowell et al. 2009; Srinivas and Pandey 2012; Meints et al. 2018), decrease hygroscopicity, and improve durability against weathering, among other characteristics in wood (Kamdem et al. 2002; Kocaefe et al. 
2007; Herrera et al. 2015; Li et al. 2017; Croitoru et al. 2018; Shen et al. 2018; Wood et al. 2018). All these improvements have a close relationship to wood chemical and physical modification, which change as a result of thermal degradation. Research has been conducted to analyze the physical characteristics and chemical components of wood products after thermal modification (Priadi and Hiziroglu 2013; Aydemir et al. 2015; Croitoru et al. 2018; Herrera et al. 2018; Tomak et al. 2018), or to evaluate wood thermal degradation characteristics of wood pyrolysis (Bach et al. 2017; Haberle et al. 2017; Lin et al. 2018; Yang et al. 2018). However, few studies have focused on the volatile substance emission during wood thermal modification, which has great impact on wood properties. Moreover, recent studies on pyrolytic degradation of wood mainly have investigated high temperatures (mostly above $300{ }^{\circ} \mathrm{C}$ ). These findings fail to guide wood thermal modification because the highest temperature for wood thermal modification is approximately $240{ }^{\circ} \mathrm{C}$, and it is typically lower than $200{ }^{\circ} \mathrm{C}$ (International Thermowood Association 2003).

Wood degradation during thermal modification largely influences the physical properties of wood, including its density, strength, hardness, moisture content, biological durability, weather resistance, and dimensional stability, among others (International Thermowood Association 2003). TG-FTIR was used to analyze wood thermal modification on-site at $160{ }^{\circ} \mathrm{C}$ and $220^{\circ} \mathrm{C}$. The modification process was demonstrated through analyzing the process of wood weight loss, gaseous release, and its generation mechanism. The results can be used in the design of an improved wood thermal modification schedule to save time and energy consumption, as well as to predict wood characteristics and improve wood product quality.

\section{EXPERIMENTAL}

\section{Materials}

Beech (Fagus sylvatica) (hardwood), and pine (Pinus elliottii) (softwood), which are two of the most widely known commercial tree species in the wood industry, were used as samples. These wood species were obtained from YuXiang Wood Products Co., Ltd., GuangXi, China. The samples were ground into powder. Then they were dried in a chamber for $24 \mathrm{~h}$ at $103{ }^{\circ} \mathrm{C}$ to the oven-dried mass.

\section{Methods}

Thermogravimetric analysis of the samples was carried out under an $\mathrm{N}_{2}$ atmosphere using a computerized thermobalance (STA449F3, Netzsch, Bavaria, Germany). The $\mathrm{N}_{2}$ flow continually flushed the apparatus at a fixed rate of $100 \mathrm{~mL} / \mathrm{min}$. To prevent the possible effects on heat and mass transfer within the inner wood during heat treatment, a $10 \mathrm{mg}$ sample that could pass through a 300 -mesh sieve was placed in a crucible, and the temperatures were raised to the target temperatures $\left(160{ }^{\circ} \mathrm{C}\right.$ and $\left.220{ }^{\circ} \mathrm{C}\right)$ in $1 \mathrm{~min}$ for each study. The process of volatile emission during the heat treatment process was examined using the thermogravimetric analyzer combined with Fourier transform infrared spectroscopy (FTIR). The $\mathrm{N}_{2}$ atmosphere flow, which continually flushed the apparatus at a fixed rate of $100 \mathrm{~mL} / \mathrm{min}$, swept gaseous and condensable products into the gas cell of the FTIR spectrometer (Tensor 27; Bruker Optics, Bruker, Germany). The IR scanning range was set from 500 to $4000 \mathrm{~cm}^{-1}$. All experiments were carried out in triplicate, and the average values represent the results. 


\section{RESULTS AND DISCUSSION}

\section{Wood Thermostability}

To demonstrate the thermal degradation properties of wood samples, the average values of thermogravimetry (TG) and derivative thermogravimetry (DTG) curves for beech and pine samples treated at different temperatures are presented in Figs. 1 and 2. The figure show that the mass loss rates (MLRs) for the beech and pine samples decreased over time and ultimately became constant under different conditions. The total mass loss increased with an increase in temperature. Figure 1 shows that for the beech and pine samples treated at $160{ }^{\circ} \mathrm{C}$, the total mass loss was approximately $3 \%$ following the thermal treatment. The total mass loss for beech was nearly constant at $5.3 \mathrm{~min}$ and was approximately $2.6 \%$ before $5.3 \mathrm{~min}$. The total mass loss for pine was nearly constant at $5.8 \mathrm{~min}$ and was approximately $2.5 \%$ before $5.8 \mathrm{~min}$.
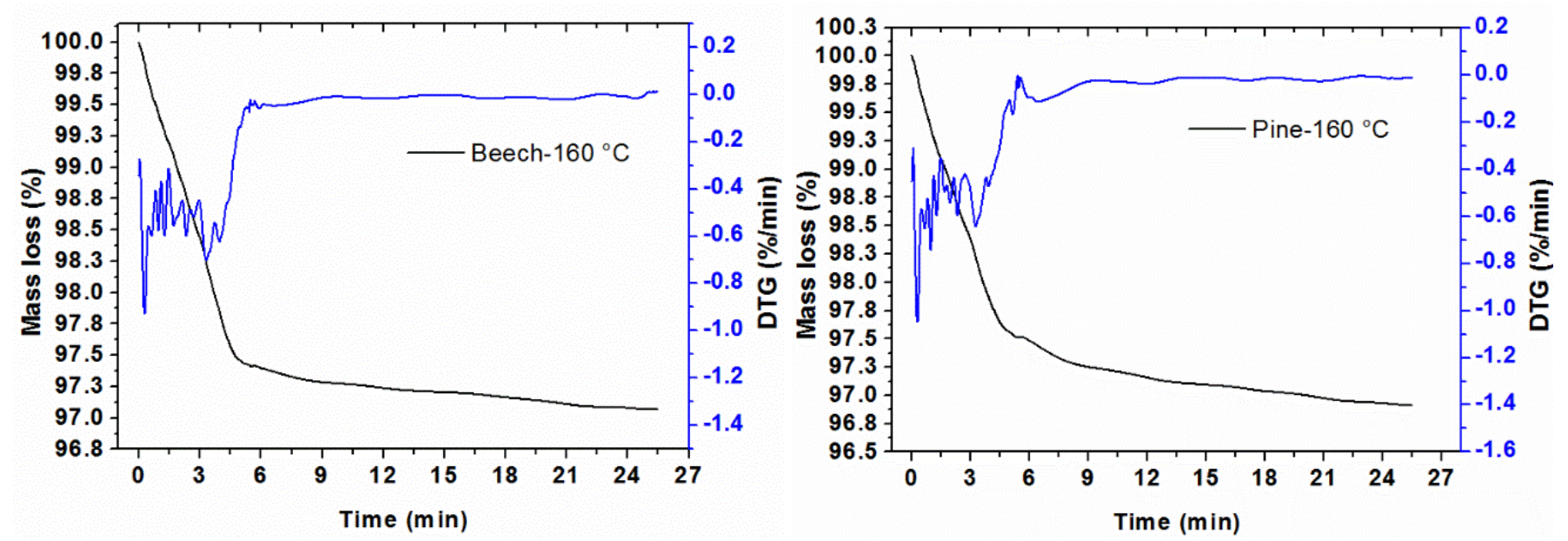

Fig. 1. TG-DTG curves of samples treated at $160^{\circ} \mathrm{C}$
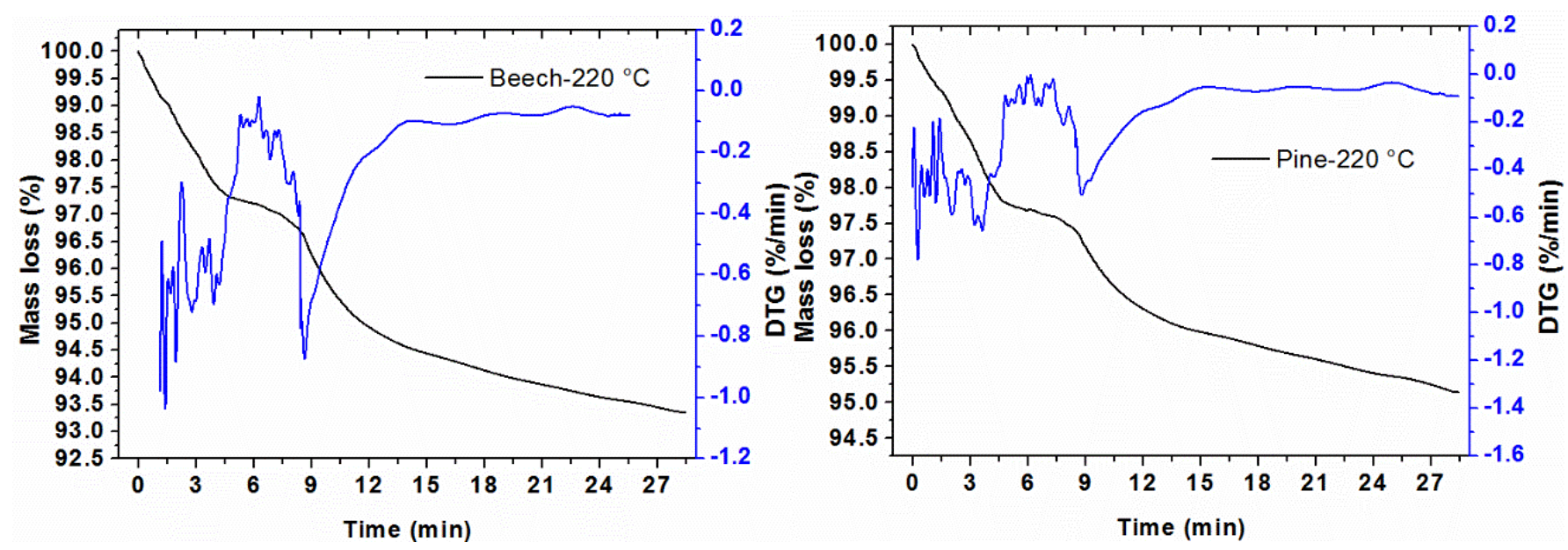

Fig. 2. TG-DTG curves of samples treated at $220^{\circ} \mathrm{C}$

Figure 2 shows that for the beech and pine samples treated at $220{ }^{\circ} \mathrm{C}$, the total mass loss was approximately $6.5 \%$ and $4.7 \%$, respectively, under the thermal treatment. The total mass loss for beech was nearly constant at $13.8 \mathrm{~min}$ and was approximately $5.5 \%$ 
before $13.8 \mathrm{~min}$; for pine, it was nearly constant at $14.6 \mathrm{~min}$ and was approximately $4.0 \%$ before $14.6 \mathrm{~min}$. Moreover, peak decomposition was observed before the mass loss became constant, and the peak increased with an increase in temperature. Most of the mass loss at the initial stage of the thermal treatment could be attributed to water retention in wood tissue (Keey et al. 2012). Even when the wood samples were dried, the evaporation of water or the low-molecular weight compounds and some extractives could lead to mass loss (Chen et al. 2011; He et al. 2018). The total mass loss for beech was larger than the loss measured for pine. The reason might have been that among the wood components, the most sensitive to thermal treatment were the hemicelluloses (Popescu et al. 2018), which comprised a larger percentage in the hardwood species (beech) than in the softwood species (pine). In addition, degradation occurs more easily in hardwood than in softwood (International Thermowood Association 2003).

\section{Characteristics of Gas Products Released and Decomposition Mechanisms}

Wood mainly consists of cellulose, hemicellulose, lignin, as well as some other extracts (Johansson et al. 1999). Cellulose constitutes approximately $40 \%$ to $50 \%$ of wood, forms the framework of wood cell walls, and is the most resistant component in the inner wood. The interlaced cellulosic microfibrils are present within a matrix composed of hemicellulose and lignin (Bauer et al. 1973). Hemicellulose constitutes approximately $25 \%$ to $35 \%$ of wood and is the least stable and the most sensitive to thermal treatment among wood's components (Popescu et al. 2018). Hemicellulose is composed primarily of xylan and mannan (Blasi and Lanzetta 1997; Shen et al. 2010). Lignin comprises $20 \%$ to $30 \%$ of wood. The structure of lignin changes when the temperature exceeds $120^{\circ} \mathrm{C}$ (Popescu et al. 2018). Extractives comprise less than $5 \%$ of wood (International Thermowood Association 2003). The degradation of wood components remarkably influences the physical properties of wood. Thus, the characteristics of gas products released from wood were analyzed to explain the degradation process of wood.

An FTIR spectrometer was used to analyze the characteristics of volatiles' emissions during thermal degradation. The concentrations of gaseous compounds present in the cell can be evaluated based on the Beer-Lambert law, which states that the concentration is proportional to absorbance of illumination when the optical system is kept constant. Different compounds can be separately evaluated at their wavenumbers of maximum light absorbance (He et al. 2018). The gas products released at different times and the corresponding temperatures are shown in Fig. 3. More gas species were released from beech than from pine, which might be due to the fact that the hemicellulose is the least stable major component in wood, and because more hemicelluloses are found in hardwood species than in softwood species (International Thermowood Association 2003; Shen et al. 2010). Moreover, the gas species released by beech increased with an increase in temperature; the variation in gas species was also greater in beech than in pine. This phenomenon could have been the reason that wood becomes unstable and some components are degraded with increasing temperature (International Thermowood Association 2003). In addition, the number of gas products increased with time, which could have been the reason why more energy was absorbed by the samples over time (Yang et al. 2018). Some extracts, or low-molecule weight components, were released, and some acids generated by hemicellulose degradation increased the degradation of other components (Tjeerdsma et al. 1998). 

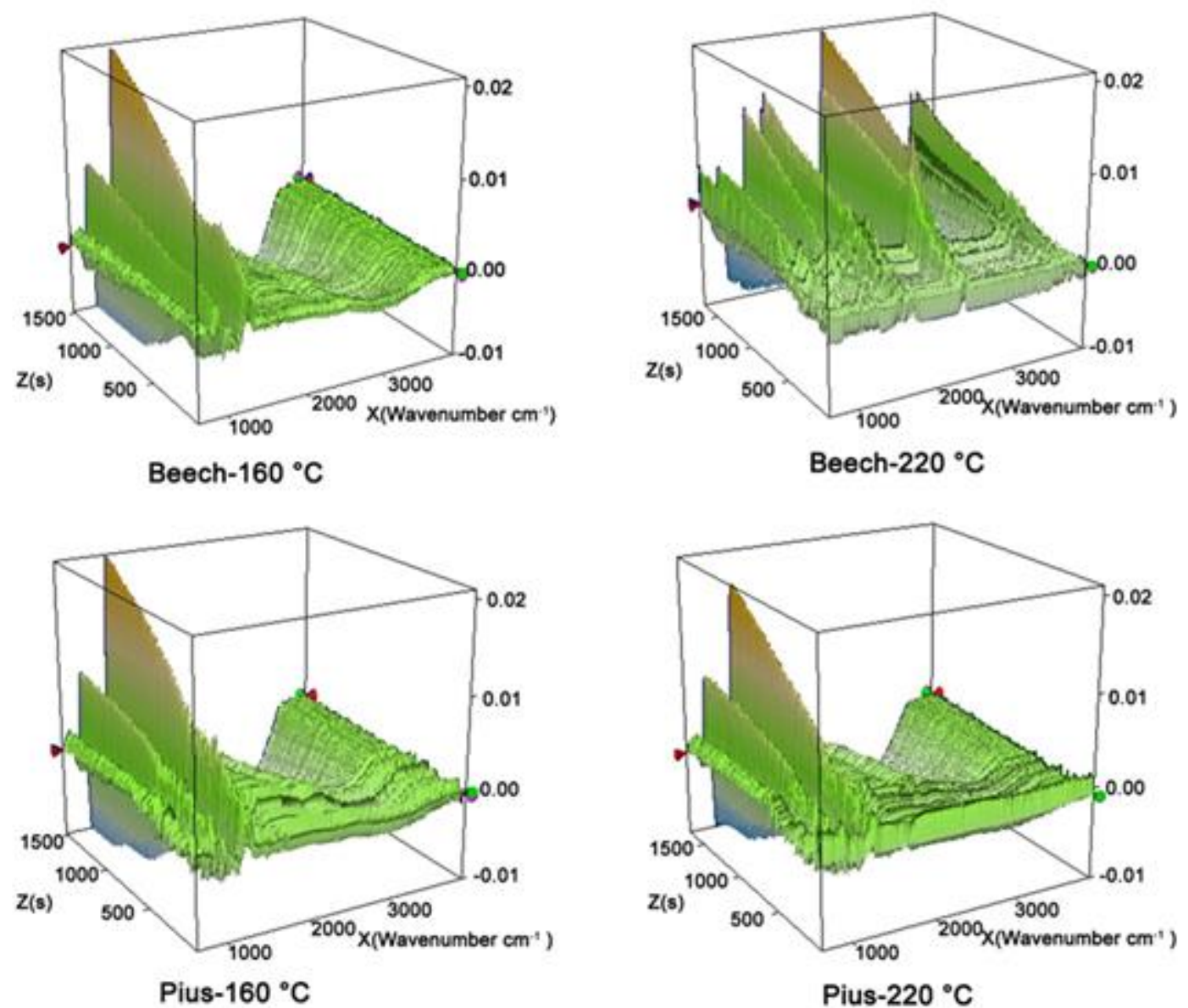

Fig. 3. Gas products released at different conditions

To elucidate the types of gas components emitted from wood under different treatment conditions, as well as the degradation mechanism of the wood samples, the FTIR spectra of the gas phase at the initial stage $(1 \mathrm{~min})$, middle $(6.0 \mathrm{~min})$, and final stages $(25 \mathrm{~min})$ of the thermal degradation are shown in Figs. 4 and 5. 

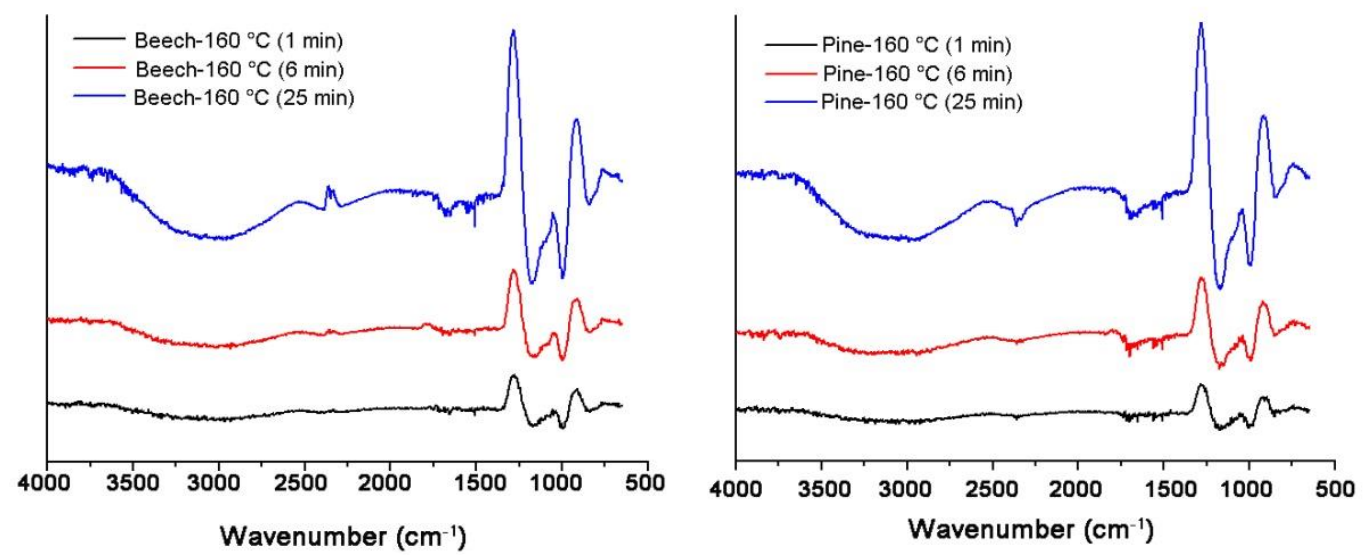

Fig. 4. FTIR spectra for samples treated at $160^{\circ} \mathrm{C}$
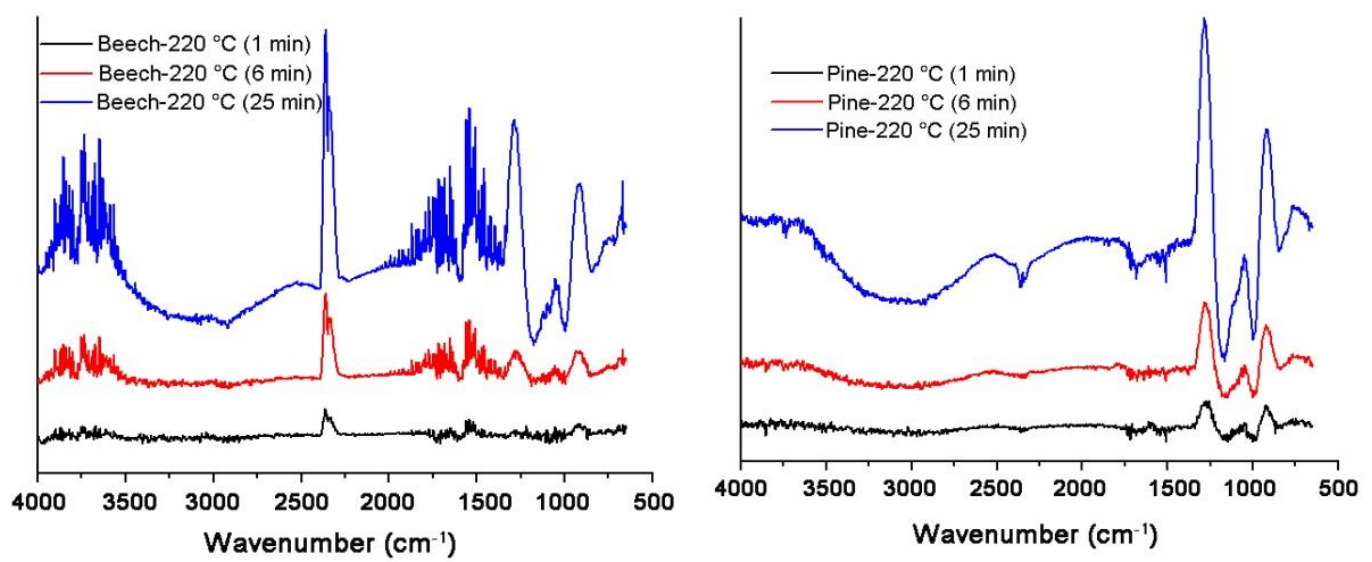

Fig. 5. FTIR spectra for samples treated at $220^{\circ} \mathrm{C}$

Figures 4 and 5 indicate that the FTIR spectra of the pine samples treated at $160{ }^{\circ} \mathrm{C}$ and $220{ }^{\circ} \mathrm{C}$ were similar, whereas the FTIR spectra of the beech samples treated at $160{ }^{\circ} \mathrm{C}$ and $220{ }^{\circ} \mathrm{C}$ were remarkably different. The intensity of the gas components in all of the samples increased as time increased. Many small peaks occurred in the ranges $1800 \mathrm{~cm}^{-1}$ to $1300 \mathrm{~cm}^{-1}$ and $4000 \mathrm{~cm}^{-1}$ to $3500 \mathrm{~cm}^{-1}$, which corresponded to $-\mathrm{OH}$ stretching in the pine samples under all conditions, in beech samples at $160{ }^{\circ} \mathrm{C}$, and at the initial stage of $220{ }^{\circ} \mathrm{C}$. Moreover, visible absorbance peaks around these wavenumbers were found in the beech samples treated at $220^{\circ} \mathrm{C}$ at $6 \mathrm{~min}$ and $25 \mathrm{~min}$. Peaks around $1800 \mathrm{~cm}^{-1}$ to $1300 \mathrm{~cm}^{-1}$ and $4000 \mathrm{~cm}^{-1}$ to $3500 \mathrm{~cm}^{-1}$ represent the evaporation of free water and bound water, or methanol in the material (Liu et al. 2008; Werner et al. 2014). The water components are generated by the cracking of aliphatic hydroxyl groups in the lateral chains (Liu et al. 2008), cross-linking reactions that occur within and between glucose molecules, and the dehydroxylation in hemicellulose and cellulose (Yang et al. 2018). Thus, water or other hydroxy components were generated during the entire process (Yao et al. 2017). The decrease in hydroxyl group content of the remaining wood can explain the improvement in the wood's dimensional stability and the decreasing hygroscopicity caused by wood thermal modification. Moreover, the absorbance intensity increased with increases in temperature and time for the beech samples, which indicated strong progression of a dehydration reaction; this could have been a prelude to char formation (Shen and Gu 2009; Zhang et al. 2015). The formation of alcohols should be 
assigned to the O-methyl group linked to the $\mathrm{C} 4$ position of the glucuronic acid unit (Ponder and Richards 1991) or cleavage of the methyl group in lignin (Popescu et al. 2018).

In addition, absorbance peaks around $1280 \mathrm{~cm}^{-1}, 1050 \mathrm{~cm}^{-1}$, and $900 \mathrm{~cm}^{-1}$, corresponding to $\mathrm{C}-\mathrm{O}$ and $\mathrm{C}-\mathrm{C}$ stretching, were observed in the beech and pine samples at $160{ }^{\circ} \mathrm{C}$ and $220{ }^{\circ} \mathrm{C}$. These absorbance peaks represented the evolution of ketones, ethers, acids, and aromatics (Liu et al. 2008; Shen et al. 2010; Gao et al. 2013; Zhang et al. 2016). These gas components were generated by the decomposition of levoglucosan, hydroxyacetone, or 5-(hydroxymethyl)-furfural, as well as other components in wood (Piskorz et al. 1989; Shen and Gu 2009; Yang et al. 2018).

Visible absorbance peaks around $2360 \mathrm{~cm}^{-1}$, corresponding to $\mathrm{C}=\mathrm{O}$ stretching, were observed in the beech samples treated at $220{ }^{\circ} \mathrm{C}$, and at the end stages of treatment at $160{ }^{\circ} \mathrm{C}$; meanwhile, no such peaks were observed in the pine samples under all conditions. This wavenumber represents the evolution of $\mathrm{CO}_{2}$ (Yang et al. 2018), which is primarily generated by the decarboxylation reaction and breakage of carbonyl groups, and the decomposition of dehydrocellulose in cellulose at low temperatures (Yang et al. 2018), or the decarboxylation of - $\mathrm{COOH}$ groups on glucuronic acid units (Patwardhan et al. 2011). It is also generated by cracking and reforming of the $\mathrm{C}=\mathrm{O}$ and $-\mathrm{COOH}$ groups (Yang et al. 2007), or the decarboxylation of O-acetyl groups linked to xylan (Shen et al. 2010), or the cleavage of the acetyl groups and carbonyl groups from the xylan chain of hemicellulose (Yang et al. 2007). The decomposition of hemicellulose, cellulose, or lignin due to the results of a decrease in water uptake, volumetric swelling values (Croitoru et al. 2018), and the decrease of wood hygroscopicity (Li et al. 2017) increase the opportunity of protection against fungal colonization and biodeterioration (Wang et al. 2018).

\section{Gas Products at Different Times}

To compare the variation in gas products between beech and pine under different conditions, the characteristics of gas product emissions over time were investigated; these are presented in Figs. 6 and 7. The quantities of most gaseous products increased over time, and this result was consistent with existing research (Popescu et al. 2018). The peak of gaseous product emissions could not be reached because the samples absorbed much more energy over time. Meanwhile, the peak decomposition temperature for cellulose, hemicellulose, and lignin could not be reached under the thermal treatment employed (Zhao et al. 2017). Some new components generated at the initial stage of the thermal treatment, such as acetic acid, could increase the rate of decomposition of hemicellulose, cellulose, and lignin over time (Tjeerdsma et al. 1998). The most gaseous products of the beech and pine samples treated at $160{ }^{\circ} \mathrm{C}$ were generated at $1280 \mathrm{~cm}^{-1}$, representing ketones, ethers, acids, and aromatics. The least gaseous products were generated around $3750 \mathrm{~cm}^{-1}$, representing water or alcohol. The gaseous products obtained from the pine samples treated at $160{ }^{\circ} \mathrm{C}$ and $220{ }^{\circ} \mathrm{C}$ were similar. However, most gaseous products obtained from the beech samples treated at $220{ }^{\circ} \mathrm{C}$ were generated around $2360 \mathrm{~cm}^{-1}$, representing $\mathrm{CO}_{2}$. 

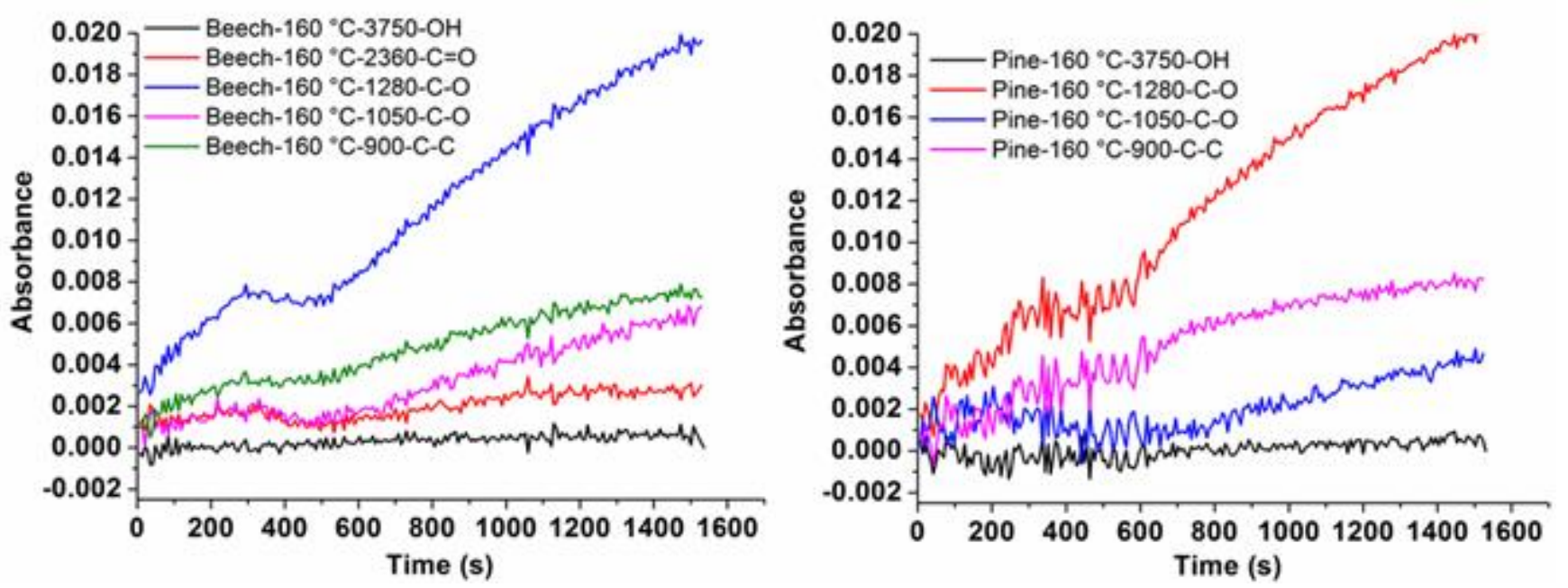

Fig. 6. FTIR spectrum of the gaseous products emissions at $160^{\circ} \mathrm{C}$
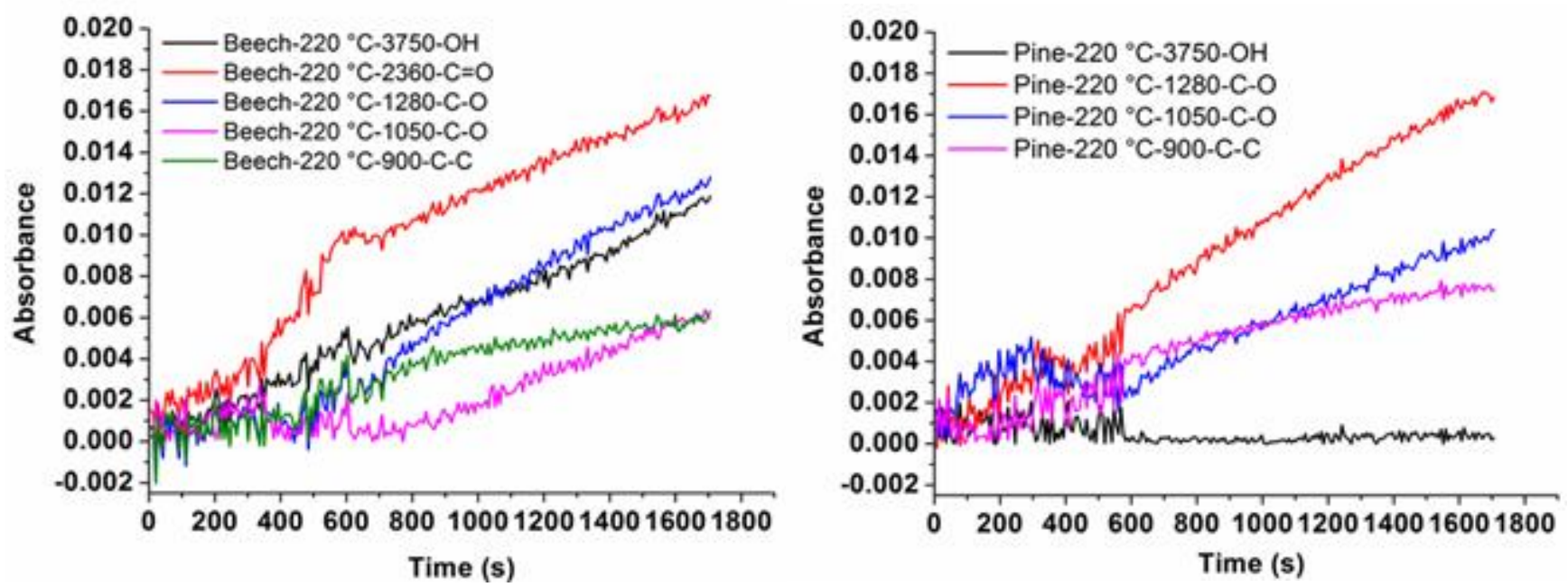

Fig. 7. FTIR spectrum of the gaseous products emissions at $220^{\circ} \mathrm{C}$

The lowest yield in gaseous products obtained from the beech samples was generated at $1050 \mathrm{~cm}^{-1}$, representing ketones, ethers, acids, and aromatics. Moreover, most wood components of beech samples decomposed at $220^{\circ} \mathrm{C}$.

\section{CONCLUSIONS}

1. The mass loss increased with increases in temperatures and time. For the samples treated at $160{ }^{\circ} \mathrm{C}$ and $220{ }^{\circ} \mathrm{C}$, the total mass losses were approximately $3 \%$ and $4.7 \%$ to $6.5 \%$, respectively. More species of gas products were emitted from the beech (hardwood) than from pine (softwood), and these species increased with increases in temperature and time.

2. The FTIR spectra of the pine samples heated at different temperatures were similar, whereas those of the beech samples were remarkable different under thermal treatment at $160{ }^{\circ} \mathrm{C}$ and $220{ }^{\circ} \mathrm{C}$. A large number of small peaks occurred at $1800 \mathrm{~cm}^{-1}$ to $1300 \mathrm{~cm}^{-1}$ and $4000 \mathrm{~cm}^{-1}$ to $3500 \mathrm{~cm}^{-1}$, which corresponded to $-\mathrm{OH}$ stretching in 
the pine samples under all the conditions, and in the beech samples at $160{ }^{\circ} \mathrm{C}$, and at the initial stage of thermal treatment at $220{ }^{\circ} \mathrm{C}$. Visible absorbance peaks around $1280 \mathrm{~cm}^{-1}, 1050 \mathrm{~cm}^{-1}$, and $900 \mathrm{~cm}^{-1}$, corresponded to $\mathrm{C}-\mathrm{O}$ and $\mathrm{C}-\mathrm{C}$ stretching, and were observed in both the beech and pine samples under all conditions. Visible absorbance peaks around $2360 \mathrm{~cm}^{-1}$ that corresponded to $\mathrm{C}=\mathrm{O}$ stretching were observed in the beech samples treated at $220{ }^{\circ} \mathrm{C}$, and at the final stage of $160{ }^{\circ} \mathrm{C}$. Meanwhile, no such peaks were observed in pine under all conditions.

3. Acid, water, or methanol, ketones, ethers, carbon dioxide, and aromatics were the main gaseous products during thermal modification. Most of the gaseous products of the beech and pine samples at $160{ }^{\circ} \mathrm{C}$ were generated at around $1280 \mathrm{~cm}^{-1}$; the gaseous products of the pine samples were similar at $160{ }^{\circ} \mathrm{C}$ and $220{ }^{\circ} \mathrm{C}$. These results can be used to guide the design of an improved wood thermal modification schedule.

\section{ACKNOWLEDGMENTS}

This research was funded by the National Key R\&D Program of China (2018YFD0600305), the Fundamental Research Funds for the Central Universities of China (2015ZCQ-CL-01), and the Hot Tracking Project in Beijing Forestry University (2017BLRD04).

\section{REFERENCES CITED}

Aydemir, D., Kiziltas, A., Kiziltas, E. E., Gardner, D. J., and Gunduz, G. (2015). "Heat treated wood-nylon 6 composites," Composites Part B: Engineering 68, 414-423. DOI: 10.1016/j.compositesb.2014.08.040

Bach, Q. V., Tran, K.-Q., and Skreiberg, Ø. (2017). "Comparative study on the thermal degradation of dry- and wet-torrefied woods," Applied Energy 185(Part 2), 10511058. DOI: 10.1016/j.apenergy.2016.01.079

Bauer, W. D., Talmadge, K. W., Keegstra, K., and Albersheim, P. (1973). "The structure of plant cell walls: II. The hemicellulose of the walls of suspension-cultured sycamore cells," Plant Physiology 51(1), 174-187. DOI: 10.1104/pp.51.1.174

Blasi, C. D., and Lanzetta, M. (1997). "Intrinsic kinetics of isothermal xylan degradation in inert atmosphere," Journal of Analytical and Applied Pyrolysis 41(97), 287-303. DOI: 10.1016/S0165-2370(97)00028-4

Chen, W., Yu, H., Liu, Y., Chen, P., Zhang, M., and Hai, Y. (2011). "Individualization of cellulose nanofibers from wood using high-intensity ultrasonication combined with chemical pretreatments," Carbohydrate Polymers 83(4), 1804-1811. DOI: 10.1016/j.carbpol.2010.10.040

Croitoru, C., Spirchez, C., Lunguleasa, A., Cristea, D., Roata, I. C., Pop, M. A., Bedo, T., Stanciu, E. M., and Pascu, A. (2018). "Surface properties of thermally treated composite wood panels," Applied Surface Science 438, 114-126. DOI:

10.1016/j.apsusc.2017.08.193 
Gao, N., Li, A., Quan, C., Du, L., and Duan, Y. (2013). "TG-FTIR and Py-GC/MS analysis on pyrolysis and combustion of pine sawdust," Journal of Analytical and Applied Pyrolysis 100, 26-32. DOI: 10.1016/j.jaap.2012.11.009

Haberle, I., Skreiberg, Ø., Łazar, J., and Haugen, N. E. L. (2017). "Numerical models for thermochemical degradation of thermally thick woody biomass, and their application in domestic wood heating appliances and grate furnaces," Progress in Energy and Combustion Science 63, 204-252. DOI: 10.1016/j.pecs.2017.07.004

He, Z. B., Qian, J., Wang, Z. Y., Yi, S. L., and Mu, J. (2018). "Effects of ultrasound pretreatment on eucalyptus thermal decomposition characteristics as determined by thermogravimetric, differential scanning calorimetry, and Fourier transform infrared analysis," ACS Omega 3(6), 6611-6616. DOI: 10.1021/acsomega.8b00382

He, Z. B., Wang, Z. Y., Zhao, Z. J., Yi, S. L., Mu, J., and Wang, X. X. (2017). "Influence of ultrasound pretreatment on wood physiochemical structure," Ultrasonics Sonochemistry 34, 136-141. DOI: 10.1016/j.ultsonch.2016.05.035

He, Z. B., and Yi, S. L. (2016). Wood Drying Theory, China Forestry Press, Beijing, China.

Herrera, R., Arrese, A., De Hoyos-Martinez, P. L., Labidi, J., and Llano-Ponte, R. (2018). "Evolution of thermally modified wood properties exposed to natural and artificial weathering and its potential as an element for façades systems," Construction and Building Materials 172, 233-242. DOI: 10.1016/j.conbuildmat.2018.03.157

Herrera, R., Erdocia, X., Labidi, J., and Llano-Ponte, R. (2015). "Chemical analysis of industrial-scale hydrothermal wood degraded by wood-rotting basidiomycetes and its action mechanisms," Polymer Degradation and Stability 117, 37-45. DOI: 10.1016/j.polymdegradstab.2015.03.013

International ThermoWood Association (2003). ThermoWood Handbook, International ThermoWood Association, Helsinki, Finland.

Johansson, L.-S., Campbell, J. M., Koljonen, K., and Stenius, P. (1999). "Evaluation of surface lignin on cellulose fibers with XPS," Applied Surface Science 144-145, 92-95.

Kamdem, D. P., Pizzi, A., and Jermannaud, A. (2002). "Durability of heat-treated wood," Holz als Roh- und Werkstoff 60(1), 1-6. DOI: 10.1007/s00107-001-0261-1

Keey, R. B., Langrish, T. A., and Walker, J. C. F. (2012). Kiln-Drying of Lumber, Springer Science+Business Media, Berlin, Germany.

Kocaefe, D., Younsi, R., Poncsak, S., and Kocaefe, Y. (2007). "Comparison of different models for the high-temperature heat-treatment of wood," International Journal of Thermal Sciences 46(7), 707-716. DOI: 10.1016/j.ijthermalsci.2006.09.001

Li, T., Cheng, D. L., Avramidis, S., Wålinder, M. E. P., and Zhou, D.-G. (2017). "Response of hygroscopicity to heat treatment and its relation to durability of thermally modified wood," Construction and Building Materials 144, 671-676. DOI: 10.1016/j.conbuildmat.2017.03.218

Lin, B.-J., Colin, B., Chen, W.-H., Pétrissans, A., Rousset, P., and Pétrissans, M. (2018). "Thermal degradation and compositional changes of wood treated in a semi-industrial scale reactor in vacuum," Journal of Analytical and Applied Pyrolysis 130, 8-18. DOI: 10.1016/j.jaap.2018.02.005

Liu, Q., Wang, S., Zheng, Y., Luo, Z., and Cen, K. (2008). "Mechanism study of wood lignin pyrolysis by using TG-FTIR analysis," Journal of Analytical and Applied Pyrolysis 82(1), 170-177. DOI: 10.1016/j.jaap.2008.03.007 
Meints, T., Hansmann, C., and Gindl-Altmutter, W. (2018). "Suitability of different variants of polyethylene glycol impregnation for the dimensional stabilization of oak wood," Polymers 10(1), 81-92. DOI: 10.3390/polym10010081

Patwardhan, P. R., Brown, R. C., and Shanks, B. H. (2011). "Product distribution from the fast pyrolysis of hemicellulose," Chemsuschem 4(5), 636-643. DOI: $10.1002 /$ cssc. 201000425

Piskorz, J., Radlein, D. S. A. G., Scott, D. S., and Czernik, S. (1989). "Pretreatment of wood and cellulose for production of sugars by fast pyrolysis," Journal of Analytical and Applied Pyrolysis 16(2), 127-142. DOI: 10.1016/0165-2370(89)85012-0

Ponder, G. R., and Richards, G. N. (1991). "Thermal synthesis and pyrolysis of a xylan," Carbohydrate Research 218, 143-155. DOI: 10.1016/0008-6215(91)84093-T

Popescu, C.-M., Navi, P., Placencia Peña, M. I., and Popescu, M.-C. (2018). "Structural changes of wood during hydro-thermal and thermal treatments evaluated through NIR spectroscopy and principal component analysis," Spectrochimica Acta Part A: Molecular and Biomolecular Spectroscopy 191, 405-412. DOI: 10.1016/j.saa.2017.10.045

Popescu, C.-M., and Popescu, M.-C. (2013). "A near infrared spectroscopic study of the structural modifications of lime (Tilia cordata Mill.) wood during hydro-thermal treatment," Spectrochimica Acta Part A: Molecular and Biomolecular Spectroscopy 115, 227-233. DOI: 10.1016/j.saa.2013.06.002

Priadi, T., and Hiziroglu, S. (2013). "Characterization of heat treated wood species," Materials \& Design 49, 575-582. DOI: 10.1016/j.matdes.2012.12.067

Rowell, R. M., Ibach, R. E., McSweeny, J., and Nilsson, T. (2009). "Understanding decay resistance, dimensional stability and strength changes in heat-treated and acetylated wood," Wood Material Science \& Engineering 4(1-2), 14-22. DOI: $10.1080 / 17480270903261339$

Shen, D. K., and Gu, S. (2009). "The mechanism for thermal decomposition of cellulose and its main products," Bioresource Technology 100(24), 6496-6504. DOI: 10.1016/j.biortech.2009.06.095

Shen, D. K., Gu, S., and Bridgwater, A. V. (2010). "The thermal performance of the polysaccharides extracted from hardwood: Cellulose and hemicellulose," Carbohydrate Polymers 82(1), 39-45. DOI: 10.1016/j.carbpol.2010.04.018

Shen, H., Zhang, S., Cao, J., Jiang, J., and Wang, W. (2018). "Improving anti-weathering performance of thermally modified wood by $\mathrm{TiO}_{2}$ sol or/and paraffin emulsion," Construction and Building Materials 169, 372-378. DOI: 10.1016/j.conbuildmat.2018.03.036

Skaar, C. (1988). Wood-Water Relations, Springer Verlag, Berlin, Germany.

Srinivas, K., and Pandey, K. K. (2012). "Effect of heat treatment on color changes, dimensional stability, and mechanical properties of wood," Journal of Wood Chemistry and Technology 32(4), 304-316. DOI: 10.1080/02773813.2012.674170

Tjeerdsma, B. F., Boonstra, M., Pizzi, A., Tekely, P., and Militz, H. (1998). "Characterisation of thermally modified wood: Molecular reasons for wood performance improvement," Holz als Roh- und Werkstoff 56(3), 149-153. DOI: $10.1007 / \mathrm{s} 001070050287$

Tomak, E. D., Ustaomer, D., Ermeydan, M. A., and Yildiz, S. (2018). "An investigation of surface properties of thermally modified wood during natural weathering for 48 months," Measurement 127, 187-197. DOI: 10.1016/j.measurement.2018.05.102 
Wang, Y., Zhang, Z., Fan, H., and Wang, J. (2018). "Wood carbonization as a protective treatment on resistance to wood destroying fungi," International Biodeterioration \& Biodegradation 129, 42-49. DOI: 10.1016/j.ibiod.2018.01.003

Werner, K., Pommer, L., and Broström, M. (2014). "Thermal decomposition of hemicelluloses," Journal of Analytical and Applied Pyrolysis 110, 130-137. DOI: 10.1016/j.jaap.2014.08.013

Wood, D., Vailati, C., Menges, A., and Rüggeberg, M. (2018). "Hygroscopically actuated wood elements for weather responsive and self-forming building parts - Facilitating upscaling and complex shape changes," Construction and Building Materials 165, 782-791. DOI: 10.1016/j.conbuildmat.2017.12.134

Yang, H., Yan, R., Chen, H., Lee, D. H., and Zheng, C. (2007). "Characteristics of hemicellulose, cellulose and lignin pyrolysis," Fuel 86(12), 1781-1788. DOI: 10.1016/j.fuel.2006.12.013

Yang, X., Zhao, Y., Li, R., Wu, Y., and Yang, M. (2018). "A modified kinetic analysis method of cellulose pyrolysis based on TG-FTIR technique," Thermochimica Acta 665, 20-27. DOI: 10.1016/j.tca.2018.05.008

Yao, Z., Ma, X., Wu, Z., and Yao, T. (2017). "TGA-FTIR analysis of co-pyrolysis characteristics of hydrochar and paper sludge," Journal of Analytical and Applied Pyrolysis 123, 40-48. DOI: 10.1016/j.jaap.2016.12.031

Zhang, B., Leng, E., Wang, P., Gong, X., Zhang, J., Zhang, Y., and Xu, M. (2015).

"Effect of reducing ends on the pyrolysis characteristics and product distribution of cellulose," Journal of Analytical and Applied Pyrolysis 114, 119-126. DOI: 10.1016/j.jaap.2015.05.007

Zhang, Y., He, Z. B., Xue, L., Chu, D. M., and Mu, J. (2016). "Influence of a ureaformaldehyde resin adhesive on pyrolysis characteristics and volatiles emission of poplar particleboard," RSC Advances 6(16), 12850-12861. DOI: 10.1039/C5RA18068F

Zhao, C., Jiang, E., and Chen, A. (2017). "Volatile production from pyrolysis of cellulose, hemicellulose and lignin," Journal of the Energy Institute 90(6), 902-913. DOI: 10.1016/j.joei.2016.08.004

Article submitted: January 31, 2019; Peer review completed: April 20, 2019; Revised version received: July 2, 2019; Accepted: July 3, 2019; Published: July 9, 2019. DOI: 10.15376/biores.14.3.6883-6894 